DP 2004/1

\title{
Alternative agricultural policy scenarios, sector modelling and indicators \\ - A sustainability assessment
}

Heikki Lehtonen

Jyrki Aakkula

Pasi Rikkonen

February 2004 


\title{
Alternative agricultural policy scenarios, sector modelling and indicators: A sustainability assessment
}

\author{
Heikki Lehtonen ${ }^{1}$, Jyrki Aakkula ${ }^{1}$ and Pasi Rikkonen ${ }^{1}$ \\ ${ }^{1}$ MTT Economic Research \\ Agrifood Research Finland \\ Luutnantintie 13, FIN-00410 Helsinki, Finland \\ heikki.lehtonen@mtt.fi \\ jyrki.aakkula@mtt.fi \\ pasi.rikkonen@mtt.fi
}

\begin{abstract}
In this article, we assess ecological, economic and social sustainability impacts of four alternative agricultural policy scenarios relevant to the European perspective. The analysed scenarios are: Prolonged Agenda 2000, On-going CAP reform, Integrated rural and environmental policy, and Liberalised Agricultural Trade. An economic agricultural sector model of Finnish agriculture is used in the evaluation of policy impacts up to 2020. Selected indicators representing the three dimensions of sustainability are calculated on the basis of the production variables of the model in each scenario. It is assumed that economic rationality, represented by the sector model, is a driving force directing agricultural production and land use, which, in turn, have a number of ecological, economic and social consequences. Our results show that a partial de-coupling of agricultural support from production and moderate reductions of commodity prices are likely to yield environmental benefits. In addition, there is a clear trade-off between environmental benefits and production volume and intensity. However, full de-coupling and radical price reductions are not likely to bring any additional environmental benefits but will result in a significant down-scaling and regional concentration of remaining agricultural activities. Hence the presented analysis is an interesting platform for discussion for stakeholders when implementing agricultural policy reforms.
\end{abstract}

Index words: agricultural policy, agricultural sector modelling, agri-environmental indicators, investments, policy dialogue, policy scenarios, production, sustainability, technical change 


\section{Introduction}

The sustainability of agriculture is an announced target of agricultural policy in both international, EU and national arenas. The problem is, however, that as well as sustainability in general, sustainable agriculture is hard to define and especially to make operational in the form of practical policy measures. One reason for this is that sustainable agriculture is, as MacRae (1990) formulates it, simultaneously a philosophy and a system of farming.

Nevertheless, despite its elusive content, sustainable agriculture is positively value-laden among the public and most stakeholders, although the views on what kind of agriculture is sustainable differ widely. In other words, there exists a shared pre-understanding of the importance of sustainable agriculture as a concept but not of its actual practices or even principles. One can even argue that the conceptual vagueness of sustainable agriculture makes it such a desirable policy goal.

In most definitions, sustainable agriculture is considered to have at least three key dimensions, namely ecological, economic and social ones. These dimensions reflect the development of sustainable agriculture, which has occurred, according to Douglass (1984), from three major perspectives: as a concept of taking care of the environment and natural resources (sustainability as stewardship), as a system of production to achieve food selfreliance (sustainability as food sufficiency) and as a vehicle for sustaining rural areas and activities (sustainability as community).

In this article, we analyse and compare the impacts of four alternative agricultural policy scenarios in quantitative terms using a set of indicators measuring changes in ecological, economic and social dimensions of sustainability. The indicator time series in alternative policy scenarios up to 2020 are calculated using an economic sector level model developed for Finnish agriculture (the DREMFIA model). Among the analysed alternative policy scenarios is a scenario mimicking likely effects of the on-going Common Agricultural Policy (CAP) reform of the European Union (EU) (Council, 2003). The other analysed scenarios are: Prolonged Agenda 2000, Integrated Rural and Environmental Policy and Liberalised Agricultural Trade. The four scenarios have been chosen based on their potential to contribute to the present Finnish as well as European policy dialogue concerning goals and ramifications of probable and desirable developments of agricultural and rural policies, where sustainability is a pronounced policy target (Commission, 2001b; Ministry of Agriculture and Forestry (MAF), 2001; Council, 2003).

Our aim is to assist policy debate by analysing and assessing the degree of sustainability of the alternative policy scenarios. The chosen approach endorses the overall goal of a policy dialogue, which is to bring together all the relevant stakeholders and facilitate their interactions and knowledge swapping in order to generate better decisions designed to enhance overall social well-being. An extensive policy dialogue is undoubtedly a prerequisite for successful completion of the on-going CAP reform agreed by the EU agricultural ministers on June 26, 2003 (Council, 2003). For example, the choice of the level and timing of de-coupling agricultural support from production, and the choice between de-coupled farm payments and de-coupled uniform area payments, or the combination of both, affects the availability and scope of other policy measures influencing ecological, economic and social sustainability. 
Our analysis is restricted to consequences taking place in Finland, but we believe that, especially within the EU context, Finland is a representative case of agriculture practised in less favoured areas ${ }^{1}$. Finland has been classified as a whole as a less favoured agricultural area (Niemi, 2003). When national or EU level agricultural policies are redesigned, less favoured areas will encounter the greatest challenges in maintaining agricultural production because of their adverse production conditions. Although in Finland the gross national product share of agriculture is currently only $1.2 \%$, the proportion of jobs in agriculture and forestry is typically more than $20 \%$ in rural areas (Statistics, 2003). Hence the role of agriculture in the rural economy is still significant, making the rural economy both sensitive and vulnerable to changes in agricultural policy.

We have chosen to apply a mathematical sector model in our analysis. A coherent, transparent and systematic framework helps in evaluating sustainability of agricultural policy alternatives by displaying the logic behind the changes in indicators in various policy scenarios. This is especially important when dealing with an issue like sustainability, which is both vaguely defined and heavily value-laden.

It is also clear that the use of indicators almost necessarily requires a quantitative approach. Although there is an on-going debate about the use and nature of sustainability indicators (Pannell et al., 2000; Rigby et al. 2001; Van der Werf et al., 2002; Gerbens-Leenes et al., 2003; Osinski et al., 2003), decision makers and other stakeholders in the agricultural sector regularly request quantitative measures of how alternative agricultural policies influence on sustainability of agriculture. The problem is that indicators are easily considered to represent a technical process of measuring certain parameters rather than a continuing re-evolution of sustainability assessment (Hakanen, 1999; Yli-viikari, 1999).

In spite of various problems and shortcomings in the application of indicators, OECD, European Commission and UN have been promoting the use of sustainability indicators since the Rio Conference in 1992 (Commission 2001a; OECD, 2001; Piorr, 2003). Consequently, Finland is also committed to the development of a national indicator framework which makes international comparisons meaningful (Yli-Viikari et al., 2002).

For the above reasons, we believe that a comprehensive mathematical sector model, which is based on economic rational production decisions and which applies indicators as a means of comparison between alternative policy scenarios, is capable of producing an added-value contribution in a policy dialogue. Our results show that a partial de-coupling of agricultural support from production and moderate reductions of commodity prices are likely to yield environmental benefits, at the expense of production intensity and production volume, which, on the other hand, are economic and societal issues. However, full de-coupling and radical price reductions are not likely to bring any additional environmental benefits but result in a significant down-scaling and regional concentration of remaining agricultural activities.

The structure of the paper is as follows. First, in Chapter 2, we present the sector model used in the calculation of indicators as well as the selected indicators and policy scenarios used in this study. Numeric values of the specific indicators in the four policy scenarios are listed and interpreted in Chapter 3. The results are further discussed in Chapter 4, where we evaluate how robust the calculated indicator changes are, and how well they cover the

\footnotetext{
${ }^{1}$ In the EU context, less favoured areas mean areas where the physical landscape or climatic conditions result in higher production costs (European, 1999).
} 
most important dimensions of sustainability. Finally, in Chapter 5, we discuss the applicability of the chosen approach and how it facilitates the policy dialogue process relevant to agricultural decision-making.

\section{Materials and methods}

\subsection{The DREMFIA sector model}

Agricultural sector modelling literature, in the domain of agricultural economics, has been traditionally dominated by studies analysing policy impacts on aggregate agricultural production and income (e.g. see a review of Bauer, 1988). However, in addition to economic analysis, it is increasingly common to calculate some environmental indicators on the basis of model results (Helming, 1997; Heckelei et al., 2001; Cooper et. al., 2003). In this study the production variables, prices and inputs, development of which are simulated by a sector model ( $c f$. Figure 1), are used in calculating economic and environmental indicators. Also some social indicators, such as labour hours in agriculture, or agricultural income per labour hour are calculated. The calculated indicators are consistent with each other and with the economic decision-making which is an important driving force in agriculture in the long run.

Agricultural investments play a key role in terms of agricultural development. Investment in new production techniques, in particular, while affecting technical change and accumulation of knowledge and skills of farmers, has wide ranging consequences in the medium and long run. However, such impacts of agricultural policy changes on aggregate agricultural investments and technical change have been paid little attention to in economic analyses. For example, the impact analyses of Mid-Term Review (MTR) proposals of the European Commission do not report effects on investment and technical change, but mainly short- or medium-term (up to 2009) impacts on agricultural production and income at the EU level (European, 2003a, European, 2003b).

In the model ( $c f$. Figure 1 ) investments in a particular technique each year are proportional to the relative difference in the profit rates of the alternative techniques, as well as to the spread of each technique, i.e. to the share of capital (out of the total capital in the sector) already invested in the technique. This means that techniques which are wider spread are more accessible to farmers because more information, knowledge and services necessary for the use of the techniques are available. If only a few farmers have invested in a particular technique then there is less knowledge and information available concerning the reliability and risks of the technique. Hence, the spread of each technique represents the accessibility and reduced risk for farmers, which may be equally important criteria in the selection of the production technique as the relative profitability of alternative techniques. Hence, the technology diffusion model may replicate self-enforcing patterns of technical change. If there are relatively small differences in the profitability of alternative techniques, i.e. in the rate of return on invested capital, those techniques which already have a larger spread, are less risky and more accessible, and they attract more investments than those which have only few users. Further investments lower the risk of the technique and increases the accumulated knowledge of farmers on how to use the technique.

However, if some new techniques are sufficiently more profitable, they gradually replace the dominant ones. To summarise, the technology diffusion model (adopted from Soete et 
al., 1984) applied is an attempt to model the behaviour of farmers whose motivation to invest is greater profitability but nevertheless will not all adopt the most profitable technique immediately, because of uncertainty, fixed assets, and various other retardation factors.

Figure 1. Basic structure of the DREMFIA model.

\begin{tabular}{|c|c|}
\hline Optimisation & \begin{tabular}{l}
\multicolumn{2}{c}{ Policy scenarios } \\
supports for farmers $\quad$ EU prices
\end{tabular} \\
\hline $\begin{array}{l}\text { MAX: producer and consumer surplus } \\
-\quad \text { annual market equilibrium } \\
-\quad \text { different yields and inputs in regions } \\
-\quad \text { feed use of animals changes endogenously } \\
-\quad \text { constraints on energy, protein and roughage } \\
\text { needs of animals } \\
-\quad \text { non-linear yield functions for dairy cows } \\
-\quad \text { domestic and imported products are } \\
\text { - } \quad \text { processing activities of milk and sugar } \\
-\quad \text { export cost functions }\end{array}$ & 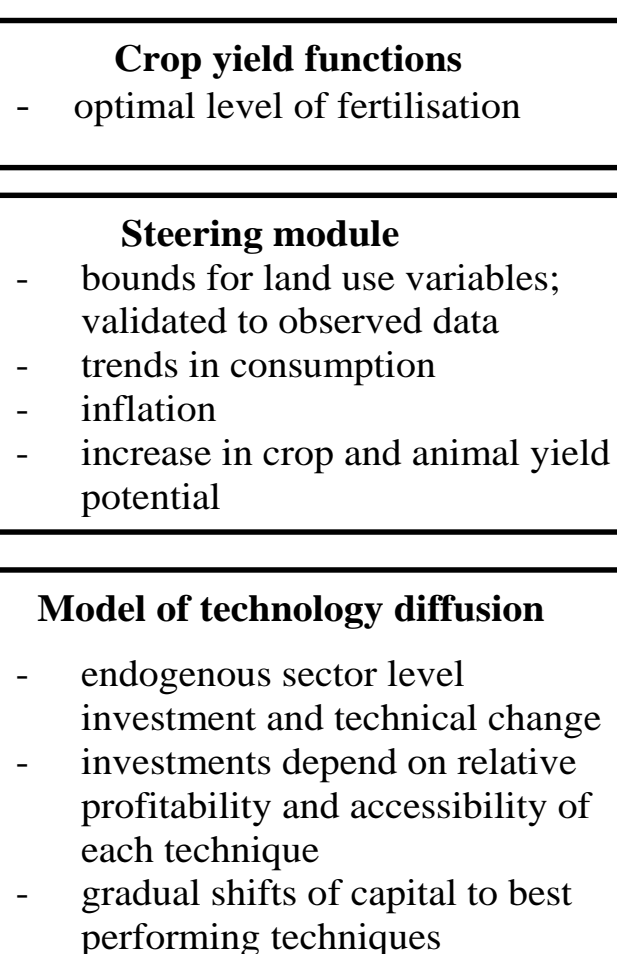 \\
\hline
\end{tabular}

The major driving force of agricultural production in the model in the medium- and longterm is the module of technology diffusion ( $c f$. Figure 1). Nevertheless, if large changes take place in production, price changes, simulated by the optimisation model, are also important to be considered. The Armington assumption is used which means that imported and domestic products are imperfect substitutes. Changes in domestic production and foreign trade of agricultural products imply price changes. Parameters of the demand system have been calibrated in order to replicate ex-post price development in 1995-2002. Optimisation provides the annual market balance using the outcome of the previous year as the initial value. There are, however, restrictions on the annual changes of some production variables. The restrictions represent short-run technical and biological constraints in each production line. The restrictions are validated in a way that annual changes may be as large as average annual changes in 1990-2002. Over this period, the policy regime of Finnish agriculture experienced major changes due to the EU accession in 1995. Hence, the changes in land use can be relatively large (10-50\%) annually, and very large up to 20152020. The model reaches a steady-state equilibrium in a 10-15 year period - if no further policy changes take place. The current situation in agricultural production and markets may include incentives for changes but these changes cannot be done immediately due to 
fixed production factors and animal biology. Hence the DREMFIA model is designed for evaluation of medium- and long-term effects of agricultural policy.

The sector model includes four main regions, Southern Finland, Central Finland, Ostrobothnia, and Northern Finland, and the production of these is further divided into sub-regions on the basis of agricultural support areas. The final and intermediate products can be transported between the main regions at certain transportation costs. Milk products and sugar are priced at the retail level. All other products are priced at the producer price level. The model caters for the most important production lines of agriculture, including crop production (14 crops), dairy production, production of beef, pork and poultry meat, as well as egg production. The open and green set-asides are also included in the model. Optimal fertilisation level is determined by fertilisation response function and crop and fertiliser prices. Animal yields grow slowly and linearly in time. Feeding affects the milk yield of dairy cows. Energy, roughage and protein needs have to be fulfilled.

No explicit connections to other sectors of the economy are made. Inflation and wage rates, price elasticity of demand and exogenous trends for consumption represent general economic conditions and changing consumer preferences. The detailed presentation of the model can be found in Lehtonen (2001).

\subsection{Agri-environmental indicators}

Here we interpret through a set of selected indicators the sustainability of agricultural development taking place in different agricultural policy scenarios. As argued earlier, the purpose is to provide material for an interactive policy dialogue rather than assemble a comprehensive and conclusive assessment of sustainability of various agricultural policy alternatives.

The selection of applied indicators is based on both policy relevance and applicability in the DREMFIA model framework. The chosen indicators form a balanced sample representing practically the official agri-environmental indicator system in Finland (MAF, 1998; MAF, 2002; Yli-Viikari et al., 2002). Perfect compatibility in this case is not the preliminary target, but to present the alternative policy scenarios and how the chosen sustainability indicators do develop in each policy alternative and what kind of trade-off they represent in sustainability dimensions point of view (cf. also Stoorvogel, 2003). We will discuss the most striking insufficiencies in terms of covering the relevant political topics in sustainable agriculture point of view. The examined indicators are presented in Table 1. In it, we also present what kind of agricultural development they are reflecting and what is the strategic goal of a specific indicator. It is important to realise that not only the numerical values of the calculated indicators but also their relative changes over time are important when evaluating the sustainability of the alternative agricultural policies. 
Table 1. The applied indicators, derived from DREMFIA model, in the agricultural policy scenario analysis.

\begin{tabular}{|c|c|c|c|}
\hline Applied indicator & $\begin{array}{l}\text { Measured } \\
\text { quantity }\end{array}$ & Indicator reflecting & Strategic goal of indicator \\
\hline $\begin{array}{l}\text { Total number of animal } \\
\text { units up to } 2020\end{array}$ & animal units & $\begin{array}{l}\text { The scales and long-term economic } \\
\text { viability of aggregate animal } \\
\text { production }\end{array}$ & $\begin{array}{l}\text { To conclude the relative economic } \\
\text { viability of animal production in } \\
\text { different policy scenarios }\end{array}$ \\
\hline $\begin{array}{l}\text { Number of bovine animal } \\
\text { units }\end{array}$ & animal units & $\begin{array}{l}\text { The scales and long-term economic } \\
\text { viability of dairy and beef } \\
\text { production }\end{array}$ & $\begin{array}{l}\text { To conclude the relative economic } \\
\text { viability of dairy and beef production } \\
\text { in different policy scenarios }\end{array}$ \\
\hline Number of pig animal units & animal units & $\begin{array}{l}\text { The scales and long-term economic } \\
\text { viability of pig production }\end{array}$ & $\begin{array}{l}\text { To conclude the relative economic } \\
\text { viability of pig production in different } \\
\text { policy scenarios }\end{array}$ \\
\hline $\begin{array}{l}\text { Number of poultry animal } \\
\text { units }\end{array}$ & animal units & $\begin{array}{l}\text { The scales and long-term economic } \\
\text { viability of poultry production }\end{array}$ & $\begin{array}{l}\text { To conclude the relative economic } \\
\text { viability of poultry production in } \\
\text { different policy scenarios }\end{array}$ \\
\hline $\begin{array}{l}\text { Total cultivated area } \\
\text { (excluding set-aside) } \\
\text { up to } 2020\end{array}$ & hectares & Incentives for active crop production & $\begin{array}{l}\text { Changes in incentives for active crop } \\
\text { production }\end{array}$ \\
\hline Set-aside area & hectares & $\begin{array}{l}\text { Incentives for fulfilling cross } \\
\text { compliance criteria and minimising } \\
\text { costs }\end{array}$ & $\begin{array}{l}\text { Changes in incentives in fulfilling } \\
\text { cross compliance criteria and } \\
\text { minimising costs in different policy } \\
\text { scenarios }\end{array}$ \\
\hline Unused area & hectares & $\begin{array}{l}\text { Share of abandoned agricultural land } \\
\text { due to unprofitable production }\end{array}$ & $\begin{array}{l}\text { Changes in the share of abandoned } \\
\text { land due to unprofitable production in } \\
\text { different policy scenarios }\end{array}$ \\
\hline Grass area & hectares & $\begin{array}{l}\text { The scale of grass feed production; } \\
\text { Incentives for grass feed use and } \\
\text { bovine animal production }\end{array}$ & $\begin{array}{l}\text { Changes in scales and incentives for } \\
\text { grass feed production in different } \\
\text { agricultural policy scenarios }\end{array}$ \\
\hline Grain area & hectares & $\begin{array}{l}\text { The scales and incentives for grain } \\
\text { production }\end{array}$ & $\begin{array}{l}\text { Changes in scales and incentives for } \\
\text { grain production in different policy } \\
\text { scenarios }\end{array}$ \\
\hline $\begin{array}{l}\text { Nitrogen balance on } \\
\text { cultivated area }\end{array}$ & $\mathrm{kg} / \mathrm{ha}$ & $\begin{array}{l}\text { Nitrogen leaching potential from } \\
\text { cultivated land }\end{array}$ & $\begin{array}{l}\text { Changes in nitrogen leaching potential } \\
\text { in different policy scenarios }\end{array}$ \\
\hline $\begin{array}{l}\text { Phosphorous balance on } \\
\text { cultivated area }{ }^{1}\end{array}$ & $\mathrm{~kg} / \mathrm{ha}$ & $\begin{array}{l}\text { Phosphorous leaching potential from } \\
\text { cultivated land }\end{array}$ & $\begin{array}{l}\text { Changes in phosphorous leaching } \\
\text { potential in different policy scenarios }\end{array}$ \\
\hline Agricultural income & Million $€$ & $\begin{array}{l}\text { The level of economic activities in } \\
\text { agriculture }\end{array}$ & $\begin{array}{l}\text { Changes in the level of economic } \\
\text { activity in different policy scenarios }\end{array}$ \\
\hline Profitability coefficient $^{2}$ & & $\begin{array}{l}\text { Profitability of agricultural } \\
\text { production }\end{array}$ & $\begin{array}{l}\text { Changes in profitability of agricultural } \\
\text { production in different policy } \\
\text { scenarios }\end{array}$ \\
\hline $\begin{array}{l}\text { Labour hours in } \\
\text { agriculture }\end{array}$ & $\begin{array}{l}\text { million } \\
\text { hours }\end{array}$ & $\begin{array}{l}\text { Social sustainability of farmers, the } \\
\text { working conditions of agricultural } \\
\text { labour }\end{array}$ & $\begin{array}{l}\text { Changes in the number of people } \\
\text { employed in agriculture in different } \\
\text { policy scenarios }\end{array}$ \\
\hline $\begin{array}{l}\text { Agricultural income per } \\
\text { hour of labour }\end{array}$ & $€ /$ hour & $\begin{array}{l}\text { Economic and social welfare of } \\
\text { farmers }\end{array}$ & $\begin{array}{l}\text { Changes in the economic and social } \\
\text { viability of agriculture in different } \\
\text { policy scenarios }\end{array}$ \\
\hline
\end{tabular}

1 The soil surface nitrogen and phosphorus balances are calculated as the difference between the total quantity of nitrogen or phosphorus inputs entering the soil and the quantity of nitrogen or phosphorus outputs leaving the soil annually, based on the nitrogen or phosphorus cycle.

2 The profitability coefficient is a ratio obtained when the agricultural surplus is divided by the sum of the entrepreneur family's salary requirement and the interest requirement on capital invested. 
In addition to the interpretation presented in Table 1, we briefly examine some sustainability relevant aspects of the chosen indicator set. One should note that the meaning of the indicators is context specific (the special circumstances in Finland) and, in some cases, dependent on the structure of the DREMFIA model which is used to compute numeric values of the indicators.

Total number of animal units, number of bovine, pig, and poultry animal units. Animal unit is a measure that transforms the number of animals in such a way that the scales of production activity of different animal production lines are comparable. In relation to economic sustainability, the number of animal units reflect changes in profitability of animal production in the long-term. The reduction in the number of animals may, in turn, endanger national food security, which is an important societal sustainability issue. When considering ecological sustainability the number of animal units has to be compared to the amount of total cultivated area, i.e. the animal density is connected to ecological sustainability; lower animal density implies higher environmental benefits. Also the species of animals count. Bovine animals are usually considered better than swine or poultry because of their closer link to grass production, which, in turn, favours biodiversity to greater extent than grain production.

Total cultivated area, set-aside, unused, grass, and grain area. The share of cultivated area is only $8 \%$ of total area of Finland. Diminishing total cultivated area may pose a risk to both economic and social sustainability of agriculture. What comes to ecological sustainability, a slight decrease in the amount of total cultivated area is probably not an ecological threat, but excessive changes in the amount of total cultivated area could severely reduce the number of different agricultural biotopes and thus jeopardise agricultural biodiversity. However, it is not only the amount of total cultivated area which counts: especially ecological but partly also economic (and even social) sustainability depends on the diversity of cultivated land use. Monoculture type farming easily creates ecological and economic risks.

Nitrogen balance on cultivated area, phosphorous balance on cultivated area. Balance means here farm gate balance of nutrients, i.e. the difference between incoming nutrients per hectare, and the outgoing nutrients (through harvested crops) per hectare. Hence the nutrient balances represent the nutrient leaching potential from agricultural lands. The most severe environmental problem in Finnish agriculture is considered to be nutrient leaching from fields to water systems (Lankoski et al., 2001). So, in ecological and environmental senses, any line of development, which reduces nutrient leakage, is considered to increase sustainability (cf. also Sacco et al., 2003).

Agricultural income. The level of agricultural income does not provide information on economic sustainability as such, because it merely reflects the overall economic activity in agriculture. However, the level of economic activity in agriculture may have considerable social and rural economic implications, at least in sparsely populated areas.

Profitability coefficient. The profitability coefficient is a ratio obtained when the agricultural surplus is divided by the sum of the entrepreneur family's salary requirement and the interest requirement on capital invested. The profitability coefficient is dependent on return requirements for labour and capital, which are exogenous in the model. Changes in the profitability coefficients obtained from the DREMFIA model are significant only in the short-term. This is because only those activities which are sufficiently profitable can 
increase or retain their levels in the long-term. In other words, the DREMFIA model accepts only profitable activities, and the profitability coefficient is the weighted average profitability of non-zero activities. However, policy changes imply temporary changes in profitability coefficient since all activities cannot fully adjust immediately due to fixed assets and other frictions in adjustment of agricultural production. Hence, any temporary negative changes in profitability coefficient show problems in profitability.

Labour hours in agriculture. The total amount of labour hours in agriculture is a socioeconomic indicator; changes in agricultural labour force have social implications. When considering social sustainability, however, one also has to consider agricultural income per hour of labour. As a time series, it shows how the labour productivity develops in agriculture. It provides a basis to compare the agricultural labour productivity to the labour productivity of other economic activities.

\subsection{Policy scenarios}

The formation of the selected agricultural policy scenarios is especially guided by their contemporary policy relevance and general principles of scenario building. On one hand, the selected scenarios should be able to provide information about likely impacts of the already accepted reform measures of the Common Agricultural Policy. On the other hand, the selected scenarios should also cover policy alternatives, which are not currently considered probable but nevertheless possible. Consequently, the four agricultural policy scenarios analysed in this work are: Prolonged Agenda 2000 or Base scenario (BAS), Ongoing CAP Reform (REF), Integrated Rural and Environmental Policy (INT) and Liberalised Agricultural Trade (LIB).

Base (BAS) scenario follows Agenda 2000 reform (agreed in Berlin 1999) which is assumed to stay unchanged up to 2020. Thus, the BAS scenario is a so-called business-asusual scenario, which in scenario work acts as a reference point for comparisons. Following the cuts in the EU intervention prices of butter and skimmed milk powder it is assumed that also the EU level market prices of butter and skimmed milk powder are assumed to fall by $15 \%$, as well as the milk fat and skimmed milk values in each dairy product in 2005-2008. Consequently, prices of dairy products as well as the producer price of milk will fall, but slightly less than $15 \%$ due to responsive supply. LFA, environmental and national support are assumed to stay at 2003 year up to 2020. The BAS scenario provides a relevant point of comparison for other policy scenarios.

On-going CAP reform (REF) scenario follows the CAP reform agreement made in June 262003 (Council, 2003). EU farm ministers agreed on partial de-coupling of CAP-support from production. 75\% of CAP area support and approximately 70\% of CAP animal support (payments per animal) based on 2000-2002 historical production levels would be paid in a single farm payment each year, beginning in 2005. However, land has to be kept in good condition in order to receive the farm payment. In practice, this means that land has to be cultivated or kept as set-aside land. Land abandonment or forest planting, for example, would not be possible. Nevertheless, receiving CAP support no longer requires any production.

The intervention price of butter and skimmed milk powder will decrease by $25 \%$ and $15 \%$, correspondingly, in 2004-2007. The REF scenario assumes that in the EU markets the skimmed milk powder prices, as well as the skimmed milk component in each dairy 
product will decrease the full $15 \%$ from 2003. The price of butter and the milk fat component in each dairy product decrease in full by 25\% in the EU markets up to 2007. The overall change in the average producer price of milk at the EU level would be $-22 \%$ from the 2003 price level up to 2007. The price of dairy products in Finland, as well as the producer price of milk in Finland (to be reported in the model results) depends on the supply-demand conditions of all dairy products. The price cuts are compensated by a direct payment of $€ 35.50$ per ton of milk quota. This compensatory payment, however, becomes fully de-coupled in 2007.

Beef premiums are fully de-coupled, but slaughter premiums are assumed to be paid per animal basis ${ }^{2}$. This means that approximately $70 \%$ of CAP headage payments are decoupled. Both coupled and de-coupled CAP supports are reduced according to the dynamic modulation scheme agreed in June 25 2003. This means that CAP payments, exceeding the first $€ 5,000$ on each farm, are reduced by 5\% from the 2004 level in 2007 up to 2015.

All these matters together decrease incentives for animal husbandry and favour farmers who intend to shift from milk or beef production to crop cultivation or set-aside. LFA support (aid paid in less favoured areas), environmental and national supports, mainly paid per hectare of certain special crops and per animal, are kept at the same level as in the BAS scenario.

Integrated Rural and Environmental Policy (INT) scenario is built on the EU Commission's CAP reform proposal given at January 22 2003. The EU Commission proposed full de-coupling CAP support from production. CAP support based on 2000-2002 historical production levels would be paid in a single farm payment each year.

Commission proposed modulation of farm payments in such a way that CAP -payments exceeding $€ 5,000$ per farm would be cut by $12.5 \%$ up to 2012. Intervention prices of butter and skimmed milk powder, as well as the values of milk fat and skimmed milk component in each dairy product, are reduced by $35 \%$ and $17.5 \%$, respectively. Hence, the producer price of milk would fall by $28 \%$ in the EU. The producer price of milk in Finland would fall somewhat less than $28 \%$ up to 2009 , however, due to elastic supply. The milk price cut is compensated by payments per quota ton. Together with the "national envelope" for milk, the payment goes up to $€ 41.62$ per quota ton (prior modulation) up to 2008 . Intervention prices of wheat and barley reduce by $5 \%$ in 2004, which is to be partly compensated by a increase of area support by $€ 3$ per ton of regional reference crop yield. The EU price level of other agricultural products would be the same as in the REF scenario

In the INT scenario, environmental concerns and labour in rural areas are particularly emphasised. This means that support for grass area is increased, and labour is supported by paying €4 per hour of work for farms which have bovine animals. Furthermore, extensive production is favoured through the CAP extensification premium which is not de-coupled from production. In addition, an extra investment subsidy is paid for small farms, on the basis of labour to be used in agricultural production. LFA support is kept at year 2002 level.

The Liberalised Agricultural Trade (LIB) scenario, based on full scale agricultural trade liberalisation, includes the most drastic changes. All agricultural support is transformed

\footnotetext{
${ }^{2}$ At the time of writing, it was not yet known which alternative partial de-coupling scheme Finland will choose.
} 
into an area-based flat-rate support which is the same for all crops and is de-coupled from production. This transformation would be completed in 2010. The only requirement for receiving support is that land must be kept in good condition and cannot be abandoned. The total sum of agricultural support is decreased by $10 \%$ by the year 2014. Prices of agricultural products in the EU are 5\%-20\% lower than in the REF and INT scenarios.

\section{Indicator results from the DREMFIA model}

Meaningful interpretation of the ramifications of indicator changes requires a broad context which extends beyond the model framework when necessary. This is especially the case when indicator changes are reflected in other sectors of the economy or when potential trade-offs between different dimensions of sustainability are involved.

The development of bovine animal units is declining already in the BAS scenario (Table 2). Milk yield per dairy cow has been increasing rapidly in recent years, from 5,982 litres per dairy cow in 1995, rising to 7,000 litres per dairy cow in 2002. Even if this rate of increase is expected to slow down to 100-120 kilos per dairy cow per year by the year 2010, the fixed production quota, which effectively constrains production in the BAS scenario, will result in a reduction of dairy cow numbers (there were approximately 348,000 dairy cows in 2002). The number of suckler cows, however, increases from 28,000 suckler cows in 2002 up to 56,000 suckler cows by 2020. Because of the increase of the number of suckler cows and heavier slaughter weights, the supply of domestic beef will gradually stabilise at 80 million kilos by 2015. This means a 10\% reduction from 2002 level.

The number of bovine animals decreases considerably in the REF scenario. There are two main reasons for this. First, producer price of milk in Finland (endogenous in the model) decrease to a level which is $15 \%-20 \%$ below the 2002 level after 2007. Second, CAP payments per milk quota ton, as well as all other CAP payments included in the single farm payment scheme, become de-coupled from production in 2008. The production costs are high in Finland because of a low crop yield level and short growing and rearing periods, as well as because of a relatively small farm size compared to many other EU countries. Hence, the simultaneous price reduction and de-coupling of support from production significantly reduce the incentive to invest in dairy farms. Milk production volume decreases by $20 \%$ up to 2015 and by $13 \%$ up to 2020 in the REF scenario ${ }^{3}$. This also means a significant reduction in the number of dairy cows and in beef production. Production of beef reduces to 66 million kilos by 2015. However, since consumers prefer domestic beef to imported beef, beef price goes up to a level which is $15 \%-20 \%$ above the 2002 beef price. This keeps the number of suckler cows still on the increase despite the decoupled beef premia. The number of suckler cows rises to 48,000 by 2020 . Hence, the beef production recovers to 69 million kilos by 2020 .

In the INT scenario, considerable support for agricultural labour and extra investments support are paid for small farms. The rate of labour support rises to $€ 4$ per hour of labour, which, however, would not be sufficient to outweigh the losses, calculated per dairy cow, caused by reduced milk price and de-coupled CAP-support. Hence, the investment in small farms would still be on the decline in the INT scenario, although at a higher level than in the REF scenario. On the other hand, extensive labour support makes investment in larger

A more detailed analysis of the Luxembourg CAP reform on Finnish dairy production can be found in Lehtonen (2004). 
production units relatively less profitable. This is because the incentive to enlarge the farm size, i.e. the additional gain from the investment compared a no investment situation, would deteriorate considerably because of the labour support. This, as well as a low milk price, would result in depreciating capital stock on dairy and beef farms and in deteriorating production facilities. Consequently, milk production volume would decrease by more than $25 \%$ by 2015 and $22 \%$ by 2020 , and the producer price of milk would remain $15 \%$ below the 2002 level. The number of suckler cows, however, would increase up to 50,000 by 2020 because of lack of domestic beef and increasing beef prices. Also, labour support and increased support on grass area facilitate the increase of suckler cows. Despite this, the total bovine animal units decrease by 33\% by 2020 from the 2002 level.

In the LIB scenario, the EU prices of milk products are at the same level as in the INT scenario, but the EU beef price decreases by $10 \%$. Since all agricultural support is areabased flat-rate support in the LIB scenario, all revenues of animal production come solely from reduced market prices. In terms of milk and beef production, this would mean rapidly decreasing production and animal unit levels. Milk production would reduce very rapidly by $41 \%$ up to 2015 and by $39 \%$ up to 2020 . This, in turn, would mean that the main part of domestic demand for cheese as well as for some fresh milk products would be imported. Since there is a lack of milk on domestic markets and liquid milk cannot be transported over long distances, the producer price of milk increases to a level which is $0 \%-10 \%$ higher than the 2002 price level. Also, beef prices do not decrease fully to the world market price level in the LIB scenario due to a drastic reduction in domestic production. The price signals, however, are sufficient only to stop the decline of milk and beef production, but not to increase production from the low levels due to be reached in 2015. This is due to high production costs in Finland because of climatic and structural inefficiencies. The overall bovine animal units decrease by $46 \%$ from the 2002 level by 2020 in the LIB scenario.

Agricultural policy changes have less drastic effects on pig and poultry production (Table 3) compared to the effects on milk and beef production. This is due to the fact that no major economic changes, compared to the BAS scenario, are expected for pork and poultry. There are no intervention mechanisms or production quotas which would slow down major changes in farm structure and regional allocation of production of pork and poultry. In the BAS scenario pork production volumes are gradually decreasing. The production covers domestic consumption whereas exports, which amounted to 18.9 million kilos (11\% of the total production) in 2001, gradually decrease considerably in the longterm. This means that production still covers $95 \%$ of domestic consumption in 2020. In the INT and LIB scenarios pork production is lower in 2020 than in the BAS scenario, since there is less grain production due to de-coupled CAP payments and lower grain prices.

Poultry production increases rapidly in Finland because of rapidly growing demand up to 2005 in the BAS scenario. The consumption of poultry meat, which has traditionally been lower per capita than in many EU countries, gradually reaches a level close to the EU average. However, there is a small temporary increase in poultry production in the REF scenario, and a significant increase in the INT scenario in 2005-2010. This is due to the fact that grain prices reduce by $5 \%$ in the INT scenario. In the long-term, however, lower grain prices and de-coupling in the INT scenario also implies that grain supply is lower than in the BAS scenario. Hence, both pork and poultry production decreases below the BAS scenario level in the INT scenario up to 2020. In the LIB scenario both pork and poultry production reduces significantly in the long-term because of low prices, but their 
prices recover slightly due to decreasing supply. Hence, the equilibrium level of pork and poultry animal units is approximately $14 \%$ below the BAS scenario level.

Tables 4 and 5 show that full de-coupling of CAP supports from production in the INT scenario, and especially the de-coupling of all agricultural support from production in the LIB scenario results in rapidly increasing set-aside areas and shrinking total cultivated area. Such development takes place especially in Northern and Eastern Finland which are areas dominated by dairy and beef production. The decreasing profitability of investments in dairy and beef production, as well as a relatively low crop yield level, drives land in setaside in Northern and Eastern Finland and in some dairy dominated areas also in Southern and Western Finland. However, the set-aside area increases relatively less in Southern and Western Finland.

Unused land (Table 6), where land rent is negative, increases steadily in the BAS scenario, where all support is production linked. Investments in large production units and regional concentration of dairy, pork and poultry production, and low profitability of grain production leads to gradual abandonment of less productive farm land. In the REF scenario the unused land area increases only temporarily, whereas in the INT and LIB scenarios there is no or little abandoned land. One can conclude that de-coupling will slow down or even prevent land abandonment. It has to be recognised, however, that without "cross compliance", i.e. the requirement of keeping agricultural land in good condition in order to be eligible for support, the unused area, instead of set-aside area, would increase drastically in the INT and LIB scenarios.

Grass area (Table 7) decreases at a faster rate than grain area (Table 8) in all scenarios. This is because of dairy and beef production, which require grass cultivation, is relatively less profitable than other production lines (pork, poultry and crop cultivation) in the REF, INT and LIB scenarios. The productivity growth in milk production and the substitution of grain for roughage in the feeding of dairy cows result in decreasing grass areas already in the BAS scenario. Hence, the ratio between grass and set-aside to other cultivated area ${ }^{4}$ decreases from 0.82 (2005) to 0.56 (2020) in the BAS scenario. In other scenarios, this ratio goes up at a fast rate which can be considered a positive development in terms of reduced nutrient leaching.

Only small changes are expected in production of special crops, potatoes, sugar beet and peas in the BAS, REF and INT scenarios. This is because these scenarios imply little economic changes for potato, sugar beet and peas. In the LIB scenario, however, low product prices for potatoes, peas and sugar beet result in drastically decreased areas and production. The area under these crops diminishes by $75 \%$ up to 2015 and by $90 \%$ up to 2020 in the LIB scenario.

4 This ratio can be calculated based on the figures of Tables 4,5 and 7. 


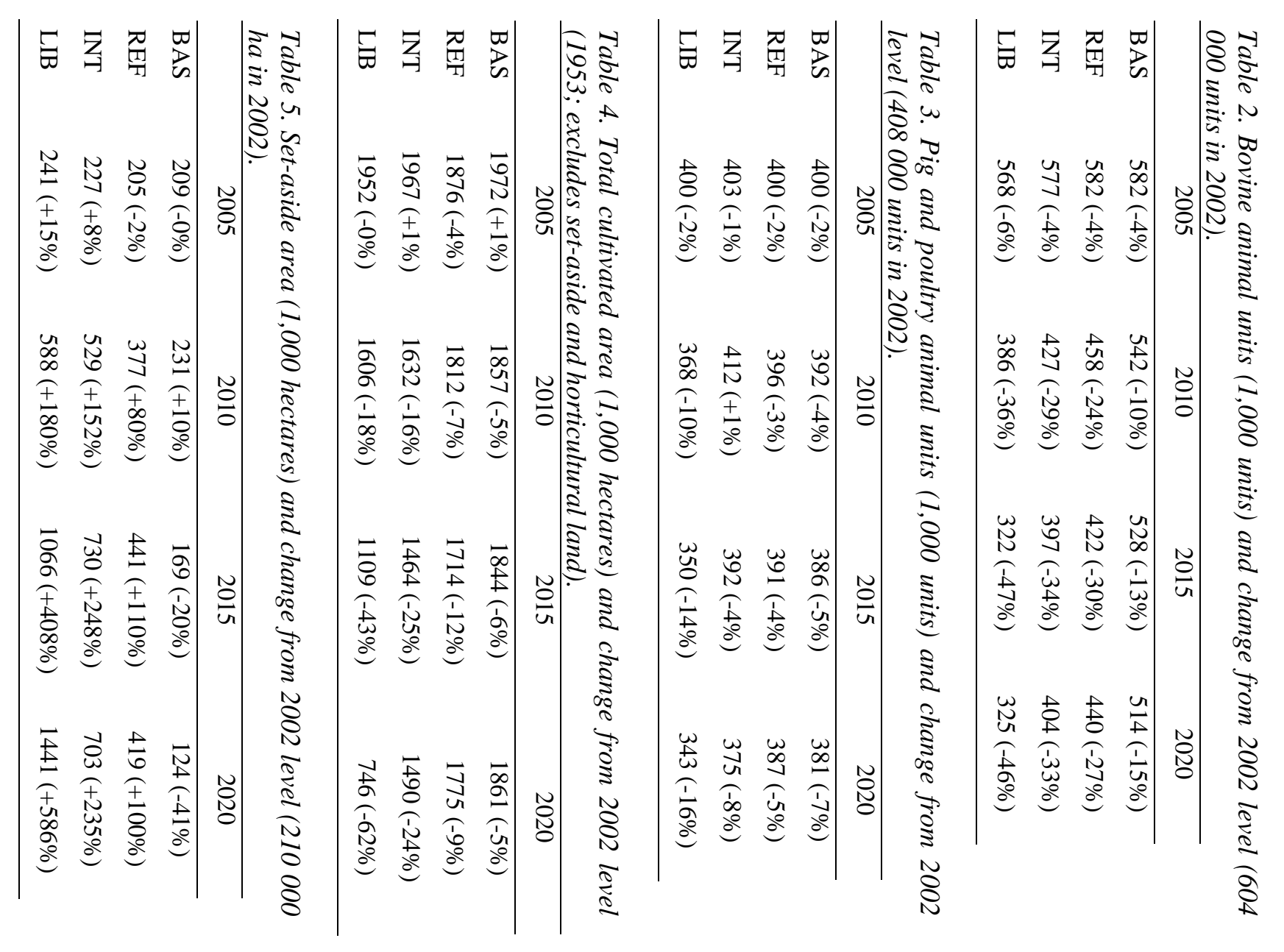

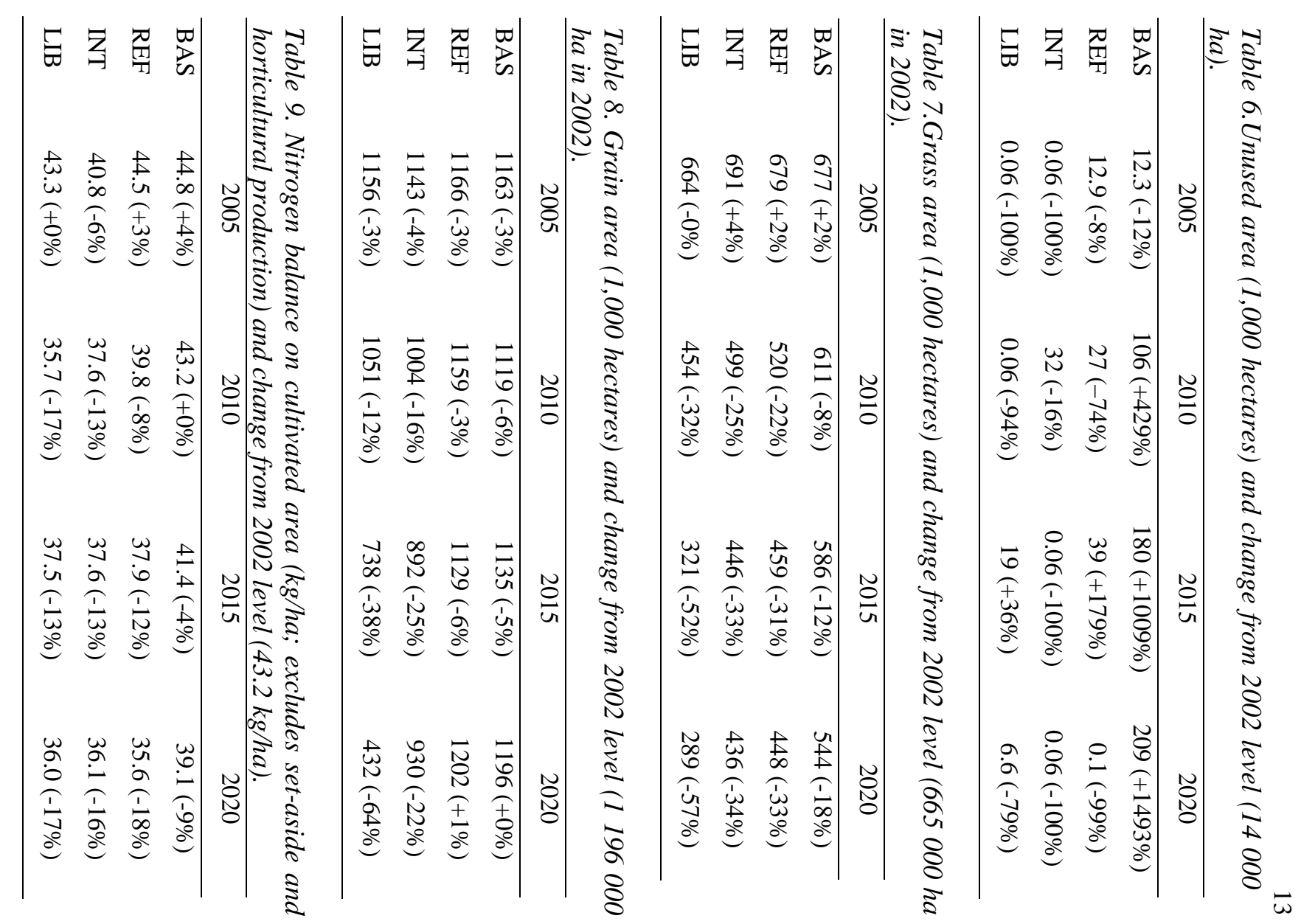




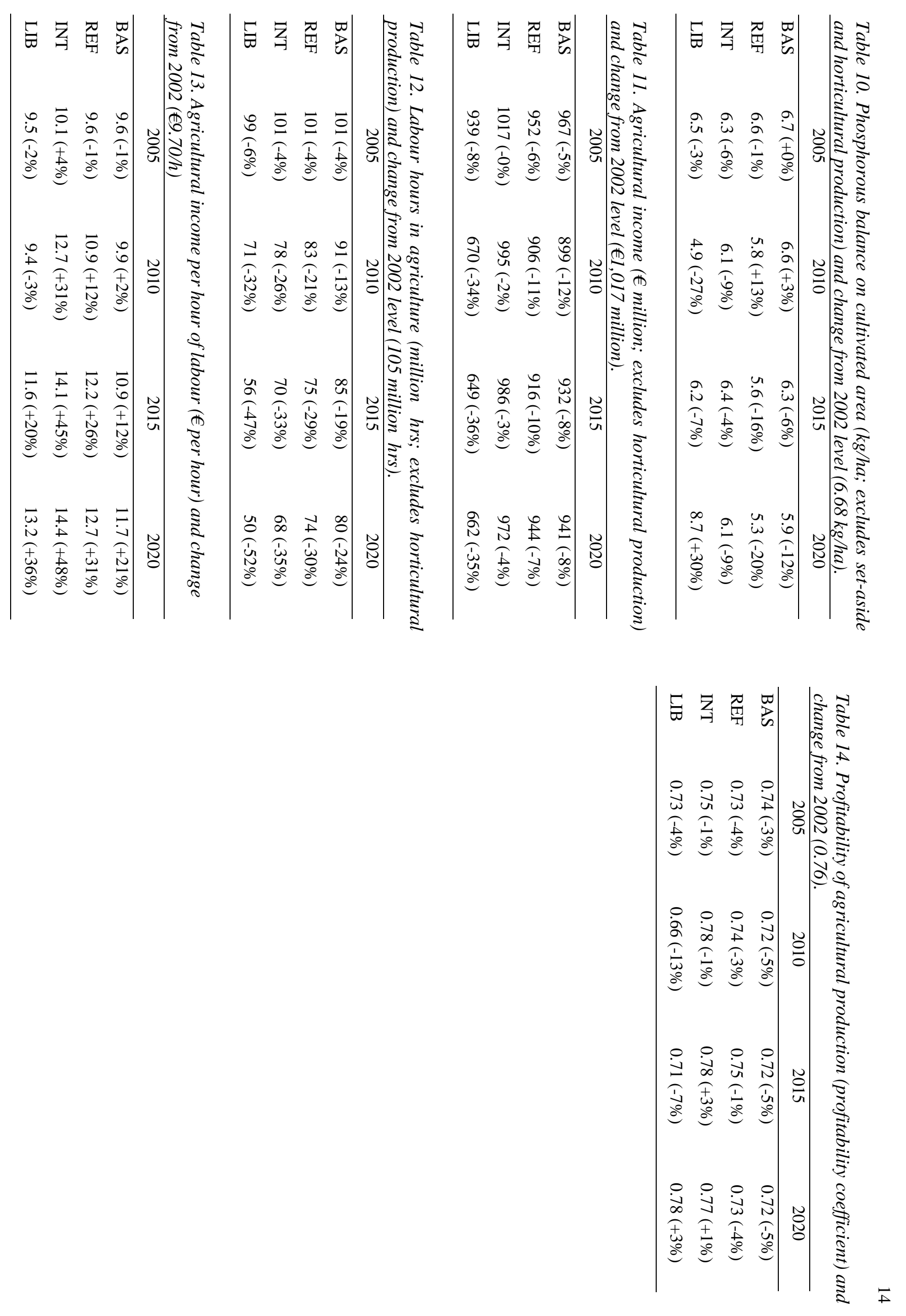


Aggregate nitrogen and phosphorous balances increase slightly in the BAS scenario up to 2005 (Tables 9 and 10), which is a joint outcome of changing feed use of bovine animals and increasing poultry production. Feeding of bovine animals changes in such a way that concentrates and various grain based feed stuffs are substituted for roughage. Consequently, grass areas decrease and more manure is spread per hectare of grassland. Nitrogen balance decreases slightly in the BAS scenario after 2010, however, mainly because of reduction of milk prices by $15 \%$ in 2005-2008, and of the resulting more extensive grass cultivation. The gradual and constant reduction in nutrient balances in the BAS scenario is also due to slight continuous decline in all animals.

The REF scenario has a significant effect on aggregate nitrogen and phosphorous balances. Lower milk price and de-coupled CAP support enhances more extensive land use on dairy farms. It is remarkable that the aggregate phosphorous balance decreases most in the REF scenario, while it decreases only slightly in the INT scenario. This is explained by the lower grain prices in the INT scenario: the lower milk prices, which would lead to lower input intensity, ceteris paribus, are partially offset by lower grain prices which imply more intensive feeding practices. The modest decline in the phosphorous balance in the INT scenario is also explained by the fact that the cultivated area, especially grain, decreases relatively more than pig and poultry animal units. Hence, pork and poultry manure, which have high phosphorous contents, is spread on a diminishing grain area. Even if the input intensity on pork and poultry farms does reduce slightly in the INT scenario, the decreasing cultivated area results only in a slight decrease in phosphorous balance. For the same reasons, the LIB scenario results in a significantly higher aggregate phosphorous balance. Since production decreases very rapidly in the LIB -scenario, product prices recover to a level which, in case of milk and beef, is in fact higher than in the INT scenario. In addition to a diminishing grain area and a high phosphorous content of pig and poultry manure, the increasing phosphorous balance is further exacerbated by imports of feed grain. Hence, low-intensity cultivation decreases relatively more than high-intensity cultivation in the LIB scenario, which results in increasing phosphorous balance.

In terms of nitrogen balance, however, the reduction is of the same magnitude in the REF, INT and LIB scenarios. This is because lower milk prices reduce the optimal nitrogen level of silage in the REF scenario, and in the INT and LIB scenarios the lower nitrogen fertilisation level due to lower grain prices is partially offset by the concentration of animal production and reduction of grain area.

Agricultural income (Table 11) decreases relatively less than work input (Table 12) in all the scenarios. In the BAS scenario, increasing production efficiency partly compensates the inflation of input prices, and hence, agricultural income decreases only slightly. Partially de-coupled CAP support in the REF and INT scenarios, and because of fully decoupled support in the LIB scenario also maintains agricultural income. De-coupled support increases set-aside areas which require very little production inputs but are still eligible for support. On the other hand, de-coupling reduces less profitable production activities in the long run.

The agricultural income per hour of labour ${ }^{5}$ (Table 13) is the highest in the INT scenario where considerable labour support is paid for bovine animal husbandry, and lowest in the BAS scenario. It is also remarkable that the agricultural income per hour of labour in the

$2 \%$ inflation is assumed for the price of labour in the model, i.e. the nominal wage rate increases by $2 \%$ per year from 2002, resulting in a 43\% increase in nominal wage rates up to 2020. 
REF scenario is higher than in the BAS scenario, which implies that even a partial decoupling will enhance production efficiency in short- and medium-run. However, one should recognise that the high income per labour hour in the INT and LIB scenarios is conditional on "cross compliance criteria", i.e. a high income per labour hour is possible if only little farm land maintenance is required for de-coupled payments.

Since the development of production volume varies a lot between the scenarios, the income per labour hour alone does not state the economic feasibility or sustainability of different policy scenarios. The very essence of the DREMFIA model is to use land and fixed resources in the most profitable way, and the agricultural production volume in the longterm can also be considered an indicator of economic sustainability as well as agricultural income or agricultural income per labour hour. Hence, the production levels should also be taken into account in the overall evaluation of economic sustainability, and not only the agricultural income or income per hour of labour. Hence, the low production levels and high income per labour hour in the INT and LIB scenarios show that there are stronger incentives for fulfilling cross compliance criteria than to produce.

Changes in the profitability coefficient (Table 14) are small in the BAS, REF and INT scenarios. This is because the DREMFIA model does not accept non-profitable activities in the long run. In the BAS scenario, the profitability coefficient stays at a value 0.72 from 2010 till 2020 which means that only 72\% of the target levels of income per hour of labour and own capital can be reached. The depreciating capital of smaller scale less efficient production units, which would have little value in any alternative use, largely explains the low profitability coefficient. In the LIB scenario, however, the profitability coefficient declines considerably in the period 2005-2010 but increases significantly in the period 2015-2020 while production deteriorates very fast. This means that there is a strong incentive to fulfil the minimum criteria for receiving de-coupled support while the incentive to produce decreases. Hence, the profitability coefficient as such does not imply economic sustainability of production, but the short-term reductions in profitability coefficient reflect problems in profitability.

\section{Discussion}

The most severe environmental problem in Finnish agriculture is currently considered to be nutrient leaching from lands into water systems. Thus, in the ecological and environmental sense, any line of development, which reduces nutrient leakage, is regarded as sustainable. Although nitrogen and phosphorus balances depict rather potential leaching than actual leaching, it is remarkable from the environmental quality perspective that the nitrogen balance would go down in all the scenarios. It is also noteworthy that the REF scenario results in a greater decline on the nutrient balances than in the BAS scenario, in which the nutrient balances reduce only slightly. No further decline in the nutrient balances, compared to the REF scenario, can be obtained in the INT and LIB scenarios. On the contrary, the phosphorous balance may increase in the LIB scenario because of the concentration of production in a few areas and because of imports of feed grain.

What occurs in biodiversity, in all the scenarios, particularly set-aside and to a minor extent also unused areas, increases at the expense of grass and grain areas. However, this kind of development does not necessarily represent an ecological hazard from the biodiversity point of view, but especially in the case of the LIB scenario, it is a sign of worrying downscaling of agricultural activity, which would most likely severely endanger 
the fulfilment of societal goals of agriculture. The reduction of grass area can also be of concern from the biodiversity perspective, but the key factor in this respect is the scale of grazing, not the sheer extent of area under grass. For this reason, the reduction in the number of bovine animals, which takes place especially in the INT and LIB scenarios, can be assumed to endanger agricultural biodiversity.

In an analysis of trade liberalisation - the simultaneous and full elimination of all trade distorting agricultural supports in all countries - effects on U.S. agriculture, Cooper et al. (2003) report only marginal changes on aggregate livestock numbers, but there were some variation on regional levels. For example, Cooper et al. (2003) report dairy production to fall nationally, while many regions exhibit increases in production. This is an indication of specialisation of production in the most feasible and competitive areas. It is also likely that a significant reduction of livestock production in Finland would be replaced by increasing production elsewhere in the EU. It would be interesting to find out the likely location and scale of the resulting production increase in Europe together with the resulting environmental and societal effects.

The steep decrease in agricultural income in the INT scenario indicates that the number of farms sharing agricultural income must decrease, or otherwise farm economies will deteriorate as well. In this respect, the decline of agricultural income sends out a worrying signal in terms of economic sustainability.

Nevertheless, the development of farm economics in the INT and LIB scenarios does not seem so disturbing when changes in the profitability coefficients are considered. Somewhat surprisingly, it appears that changes in the profitability coefficients are rather minimal in all the scenarios. One reason for this can be derived from the nature of the DREMFIA model - it does not allow a continuation of highly non-profitable agricultural activities. In the LIB scenario, however, the profitability coefficient declines significantly in the period 2010-2015 but increases later considerably while production deteriorates very fast. This means that there is a strong incentive in fulfilling the minimum criteria for receiving the de-coupled support while the incentive to produce decreases. However, as long as the profitability coefficient stays below one, the return to own labour and capital is less than in other sectors of rural economy. This is detrimental for a truly competitive economic activity.

The low values of the profitability coefficients are explained by the fact that, compared to other sectors in the economy, farmers accept lower return on capital and labour because of fixed assets - as agricultural production equipment have little value in other alternative uses. In this respect, all the scenarios perform poorly in terms of economic sustainability because both labour and own capital could be used more productively somewhere else in the economy. Consequently, it should be kept in mind that because the farm level economic performance is already poor in the beginning, it does not significantly deteriorate in the course of time.

The decline of agricultural income and the diminishing number of labour hours in agriculture seem to point towards the fact that the role of agriculture as a rural backbone will gradually vanish. Because the DREMFIA model does not include other rural activities besides agriculture, it is not possible to assess the nature of overall rural development. However, all the four agricultural policy scenarios lead to a considerable down-scaling of agriculture, which will inevitably be reflected to social sustainability of rural areas in a 
negative manner, if the forfeited agricultural activity is not substituted by some other rural activity.

When interpreting the results, we also have to keep in mind that sector models neglect linkages of agriculture with other sectors of the economy. If some major change in agricultural policy has significant impacts on agricultural production, the feedback from other sectors of the economy, either in the form of input prices or explicit environmental or other constraints, may affect agricultural production. This was not taken into account in the presented analysis. On the other hand, such feedback effects are not of primary importance since agriculture is a small part of the national economy.

Another limitation of the presented analysis is that the applied indicators do not cover all aspects of ecological, economic and social sustainability of agriculture. For example, longterm changes in some ecological indicators are joint outcomes of many complex biological and chemical processes and are difficult to incorporate into any simplified model framework. Although modelling results can be supplemented by expert views and other research illuminating complex ecological processes, the problem is to ensure the consistency of expert views with indicator changes taking place in the model framework. There is always a risk that the incorporation of context specific expert views or research results negatively affects the consistency of the modelling of various inter-linked indicators.

\section{Conclusions}

In this paper we have evaluated, for the purposes of a policy dialogue, the sustainability of four different agricultural policy scenarios using economic modelling and selected quantitative indicators. It seems that all four policy scenarios involve trade-offs between ecological, economic and social dimensions of sustainability. Compared to the current situation, any of the policy scenarios cannot be considered to result a better future along all the three lines of sustainability. From the policy-making perspective this is challenging because various stakeholders have conflicting views about the importance of different sustainability dimensions.

If equal weight were given for the three aspects of sustainability, the ordering of the policy alternatives would be as follows: REF (On-going CAP reform), BAS (Prolonged Agenda 2000), INT (Integrated rural and environmental policy) and LIB (Liberalised Agricultural Trade). The main trade-off would be between production levels and environmental quality. However, the REF scenario can be considered only slightly more sustainable than the BAS scenario. The gains in environmental quality in the REF scenario - especially in the form of improved nutrient balances - would be outweighed by lower production and income levels, which would undoubtedly endanger economically and socially sustainable development.

All in all, this study provides a long-term analysis of agricultural policy impacts in Finland which is a less favoured agricultural area in the EU. Investment and technical and structural change has been taken into account as an endogenous variable, which provides a deeper long-term view, ceteris paribus, on agricultural development than considerations, or analyses relying on exogenous technical and structural change. The analysis revealed that radical price reductions and de-coupling of agricultural support are likely to cease the positive technical change and result in decreasing production volumes in the long-term. 
Hence, these results indicate that in less favoured areas some production linked subsidies are necessary, at least temporarily, if balanced agricultural development, with no drastic decline of production, is desired.

When assessing the feasibility and usability of the results one can conclude that there are logical and conceivable causal relationships between the specific indicators. The economic rationality, reflected by changes in animal units and land use, and caused by changes in relative profitability between different products and production lines, is seen as a primary driving force behind agricultural development. From this perspective, ecological and social objectives play a lesser role - they are subordinated to economic incentives of decision making. Even though this point of view is somewhat simplistic (farmers may have also other objectives than profit maximisation), it is essentially this simplification which provides a clear logic in evaluating changes in different dimensions of sustainability.

It is up to relevant stakeholders to judge the potential of these observations to facilitate a policy dialogue coping with the future sustainable path of Finnish agriculture or sustainable agricultural development in general. This study provides an elaborated example of how to make with the help of selected indicators a systematic assessment of changes taking place in alternative policy scenarios. As the results show, some of the main indicators are conceivable and their interpretation is clear. Still, inevitably there remain gaps in the coverage and interpretation of the selected indicators. Despite this, we believe this analysis will help decision-makers initiate a policy dialogue about the likely sustainability impacts of the alternative agricultural policy scenarios. 


\section{References}

Bauer, S. 1988. Historical review, experiences and perspectives in sector modelling, $p p$. 3-22. In Proceedings of the 16th symposium of the European Association of Agricultural Economists, April 14th-15th, 1988, Wissenschaftsverlag Vauk Kiel KG.

Commission of the European Communities. 2001a. A framework for indicators for the economic and social dimensions of sustainable agriculture and rural development. Commission staff working paper SEC(2001)266. Brussels.

Commission of the European Communities. 2001b. Environment 2010: Our Future, our Choice. The Sixth Environment Action Programme of the European Community. COM (2001)31. Brussels.

Cooper, J., Johansson, R. \& Peters, M., 2003. Some Domestic Environmental Effects of U.S. Agricultural Adjustments under Liberalized Trade; a Preliminary Analysis. Accepted Paper. The Second North American Symposium on Assessing the Environmental Effects of Trade. March 2003, Commission for Environmental Cooperation (CEC), Mexico City, Mexico.

Council of the European Union. 2003. CAP Reform - Presidency compromise (in agreement with the Commission.(http://register.consilium.eu.int/pdf/en/03/st10/st10961en03.pdf).

Douglass, G. 1984. The meanings of agricultural sustainability, pp. 3-30 In: Douglass, G. (ed.). Agricultural Sustainability in a Changing World. Westview Press, Boulder, CO.

European Commission. 2003a. Mid-Term Review of the Common Agricultural Policy. July 2002 Proposals. Impact Analyses. February 2003. Directorate-General for Agriculture. Available on the Internet: http://europa.eu.int/comm/agriculture/publi/reports/mtrimpact/rep_en.pdf. Reference: 2004-02-10.

European Commission. 2003b. Reform of the Common Agricultural Policy. A Long-term Perspective for Sustainable Agriculture. Impact Analysis. March 2003. Directorate-General for Agriculture. Available on the Internet: http://europa.eu.int/comm/agriculture/publi/reports/reformimpact/rep_en.pdf. Reference: 2004-02-10.

European Environment Agency. 1999. Environment in the European Union at the turn of the century. European Environment Agency, Copenhagen, Denmark.

Gerbens-Leenes, P. W., Moll, H. C. and Schoot Uiterkamp, A. J. M. 2003. Design and development of a measuring method for environmental sustainability in food production systems. Ecological Economics 46: pp.231-248.

Hakanen, M. 1999. Yhdyskuntien ekologisesti kestävän kehityksen arviointi, kriteerit ja mittaaminen. Academic dissertation. The Association of Finnish Local and Regional Authorities. Acta-series, number 107.

Heckelei, T., Witzke, P. and Henrichsmeyer, W. 2001. Agricultural Sector Modelling and Policy Information Systems. In Proceedings of the $65^{\text {th }}$ European Seminar of the European Association of the Agricultural Economics (EAAE), March 29-31, Bonn, Germany.

Helming, J.F.M. 1997. Agriculture and environment after CAP reform in the Netherlands; an application of an agri-environmental sector model. Tijdschift voor Sociaalwetenschappelijk Onderzoek van de Landbouw 4: pp.334-356. 
Lankoski, J. and Ollikainen, M. 2001. Policy design for multifunctional agriculture. MTT Working Papers 6/2001. Helsinki.

Lehtonen, H. 2001. Principles, structure and application of dynamic regional sector model of Finnish agriculture. Academic dissertation. MTT Publications 98. Helsinki. 265 pp.

Lehtonen, H. 2004. Impacts of de-coupling agricultural support on dairy investments and milk production volume in Finland. Forthcoming in Acta Agriculturae Scandinavica, Section C: Food Economics. Taylor \& Francis 2004.

MAF (Ministry of Agriculture and Forestry). 1998. Uusiutuvien luonnonvarojen kestävän käytön yleismittarit. Publications 3. Helsinki, Finland.

MAF (Ministry of Agriculture and Forestry). 2001. Strategy for Finnish Agriculture. Final Report of the Steering Group, Working Group Report 16b. Helsinki, Finland.

MAF (Ministry of Agriculture and Forestry). 2002. Strategy for the Renewable Natural Resources in Finland. Publications 8b/2001. Available on the Internet: http://www.mmm.fi/english/landwater/natural_resources/Luonnonvara_Englanti.pdf

MacRae, R. J. 1990. Strategies to overcome institutional barriers to the transition from conventional to sustainable agriculture in Canada: the role of government, research institutions and agribusiness. Academic dissertation. Department of Renewable Resources, McGill University, Montreal, Canada. Available on the Internet: http://www.eap.mcgill.ca/rod_thesis/rod_1.htm.

Niemi, J. 2003. Agricultural support. Pp. 46-53. In Niemi, J. and Ahlstedt, J. 2003 (eds.). Finnish Agriculture and rural industries. MTT Publications 103a. Vammala, Vammalan kirjapaino Ltd.

OECD 2001. Environmental indicators for agriculture. Volume 3. Methods and results. Paris, France.

Osinski, E., Kantellhardt, J. and Heissenhuber, A. 2003. Economic perspectives of using indicators. Agriculture, Ecosystems and Environment 98: pp. 477-482.

Pannell, D. J. and Glenn, N. A. 2000. A framework for the economic evaluation and selection of sustainability indicators in agriculture. Ecological Economics 33: pp.135-149.

Piorr, H-P. 2003. Environmental policy, agri-environmental indicators and landscape indicators. Agriculture, Ecosystems \& Environment (Corrected Proof, Available online 19 March 2003) 2060: pp.1-17.

Rigby, D., Woodhouse, P., Young, T. \& Burton, M. 2001. Constructing a farm level indicator of sustainable agricultural practice. Ecological Economics 39: pp. 463-478.

Sacco, D., Bassanino, M. and Grignani, C. 2003. Developing a regional agronomic information system for estimating nutrient balances at a larger scale. European Journal of Agronomy 20:1999-210.

Soete, L. and Turner, R. 1984. Technology diffusion and the rate of technical change. The Economic Journal pp. 612-623.

Statistics Finland 2003. Statistical Yearbook of Finland 2002. Helsinki. 
Stoorvogel, J. J., Antleb, J. M., Crissmanc, C. C. and Bowend, W. 2003. The trade-off analysis model: integrated bio-physical and economic modelling of agricultural production systems. Agricultural Systems (Corrected proof, available online 30 October 2003).

Werf van der, H. M. G. \& Petit, J. 2002. Evaluation of the environmental impact of agriculture at the farm level: a comparison and analysis of 12 indicator-based methods. Agriculture, Ecosystems and Environment 93: pp. 131-145.

Yli-Viikari, A. 1999. Indicators for sustainable agriculture - a theoretical framework for classifying and assessing indicators. Agricultural and Food Science in Finland 8: pp. 265-283.

Yli-Viikari, A., Risku-Norja, H., Nuutinen, V., Heinonen, E., Hietala-Koivu, R., Huusela-Veistola, E., Hyvönen, T., Kantanen, J., Raussi, S., Rikkonen, P., Seppälä, A. \& Vehmasto, E. 2002. Agri-environmental and rural development indicators: a proposal. Agrifood Research Reports 5. pp. 102. 